\title{
Pengaruh Kebijakan Perpajakan dan Inflasi Terhadap Penerimaan Pajak
}

\author{
Nindita Dwi Marlyanti ${ }^{1}$, Aristha Purwanthari Sawitri ${ }^{2}$ \\ ${ }^{1}$ Prodi Akuntansi, Universitas PGRI Adi Buana Surabaya, Indonesia. \\ email: ninditadwimarlya@gmail.co \\ ${ }^{21}$ Prodi Akuntansi, Universitas PGRI Adi Buana Surabaya, Indonesia. \\ email: aristha@unipasby.ac.id
}

\begin{abstract}
Indonesia needs to make arrangements and implementation of national development aimed at realizing welfare for the community. The national development cost is derived from the largest tax sector. The objective of the research is to analyze the influence of Self Assessment System, tax audit, tax collection and inflation on VAT acceptance in KPP Pratama Surabaya Karangpilang. The documentation method is used to obtain the VAT Acceptance report data KPP Pratama Surabaya Karangpilang period 2015-2018 and written data from Bank Indonesia with purposive sampling technique. Samples obtained 48 months during the period 2015-2018. Partial research results show if only tax billing variables have an effect on VAT acceptance in KPP Pratama Surabaya Karangpilang. Based on the results of the research obtained, KPP Pratama Surabaya is expected to increase service and outreach activities in order to provide understanding and awareness of the importance of paying taxes
\end{abstract}

Keywords: Tax, PPN and Inflation

\begin{abstract}
Abstrak
Indonesia perlu melakukan penyusunan dan penyelenggaraan pembangunan nasional yang bertujuan untuk mewujudkan kesejahteraan bagi masyarakat. Biaya pembangunan nasional berasal dari sektor penerimaan negara terbesar yaitu pajak. Tujuan penelitian adalah menganalisis pengaruh Self Assessment System, Pemeriksaan Pajak, Penagihan Pajak dan Inflasi terhadap Penerimaan PPN pada KPP Pratama Surabaya Karangpilang. Metode dokumentasi digunakan untuk memperoleh data laporan penerimaan PPN KPP Pratama Surabaya Karangpilang periode 2015-2018 dan data tertulis dari Bank Indonesia dengan teknik purposive sampling. Sampel yang diperoleh 48 bulan selama periode 2015-2018. Secara parsial hasil penelitian menunjukkan jika hanya variabel penagihan pajak berpengaruh terhadap penerimaan PPN pada KPP Pratama Surabaya Karangpilang. Berdasarkan dari hasil penelitian yang didapat, diharapkan KPP Pratama Surabaya meningkatkan kegiatan pelayanan dan penyuluhan demi memberikan pemahaman dan kesadaran akan pentingnya membayar pajak.
\end{abstract}

Kata Kunci : Pajak, PPN dan Inflasi

\section{PENDAHULUAN}

Pajak merupakan kontribusi wajib orang pribadi atau badan untuk negara, dimana penyerahan wajib tersebut digunakan untuk membiayai pembangunan ekonomi di sebuah Negara sehingga pemerintah akan berusaha untuk meningkatkan penerimaan melalui pajak agar bisa membiayai pengeluaran-pengeluaran pemerintah. Data pertumbuhan penerimaan pajak pada gambar 1 dan gambar 2 yang diperoleh dari Departemen Keuangan menunjukkan adanya peningkatan penerimaan pajak setiap tahun dan sumber pendapatan didominasi oleh Pajak Penghasilan dan Pajak Pertambahan Nilai (PPN). PPN adalah pungutan kepada wajib pajak swasta atau badan yang merupakan Pengusaha Kena Pajak atas transaksi jual beli barang dan jasa.

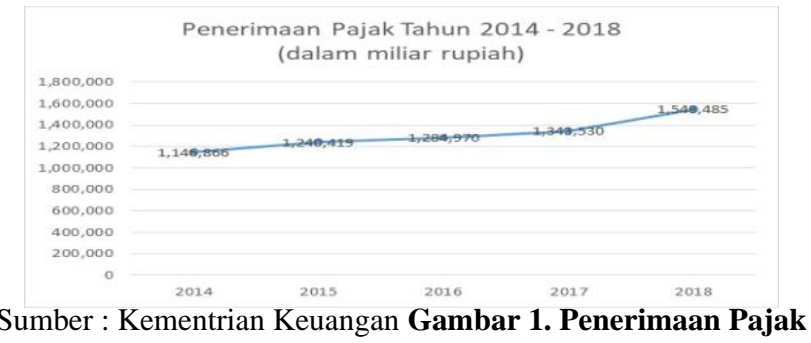




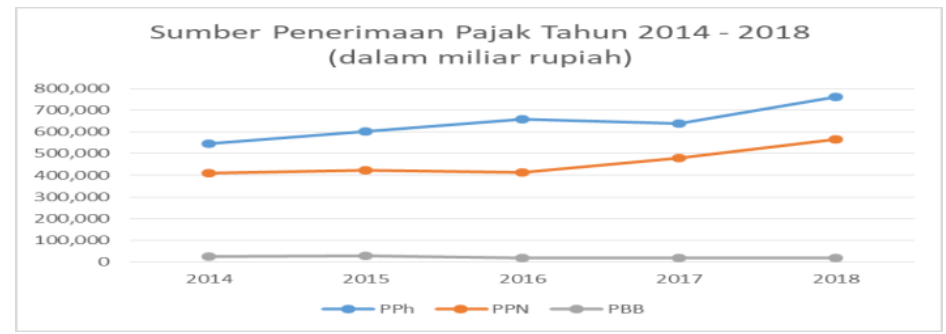

Sumber : Kementrian Keuangan. Gambar 2. Sumber Penerimaan

Pemerintah juga berusaha untuk memaksimalkan penerimaan pendapatannya yang berasal dari Pajak. Rasio Pajak tahun 2018 menunjukkan nilai $11.5 \%$ berdasarkan pada data pada website resmi Direktorat Jenderak Pajak (DJP). Rasio pajak Indonesia masuk kedalam kategori rendah jika dibandingkan dengan negara Malaysia, Filipina, Singapore dan Kamboja. Rendahnya rasio pajak ini menunjukkan pemerintah belum mampu membiayai pengeluaran negara dari penerimaan pajak.

Peningkatan penerimaan pajak tentunya membutuhkan kerjasama dari berbagai pihak. Tidak hanya dari regulasi atau peraturan pajak, tetapi masyarakat memiliki peran penting terkait dengan kesadaran pajak. Pengampunan pajak (tax amnesty) ini diharapkan sebagai stimulus kepada masyarakat untuk lebih sadar terhadap kewajiban pajaknya sehingga dengan adanya tax amnesty diharapkan dapat meningkatkan kinerja pajak negara. Optimalisasi administrasi pajak, kepatuhan perpajakan dan penyelarasan peraturan perpajakan menjadi komponen penting dalam peningkatan penerimaan pendapatan pajak.

Fluktuasi ekonomi makro Negara dan kebijakan perpajakan memiliki perananan dalam peningkatan penerimaan pajak (Renata dkk, 2016). Komponen variabel makro yang berperan penting dalam fluktuasi ekonomi salah satunya adalah inflasi. Definisi inflasi menurut Bank Indonesia adalah peningkatan secara umum dan terus menerus atas harga barang dan jasa yang akan berdampak pada perekonomian negara. Jika terjadi inflasi maka pendapatan atau keuntungan yang menunjukkan konsumsi masyarakat tidak dapat mencerminkan adanya kenaikan pendapatan atau keuntungan karena sudah terpengaruh oleh adanya inflasi tersebut dan tentunya akan berdampak pada penerimaan pajak. Konsumsi masyarakat meningkat maka akan berpengaruh terhadap jumlah penerimaan pajak (Wijayanti, 2015).

Fungsi Pajak menurut Resmi (2019) yaitu sebagai pembiayaan pengeluaran-pengeluaran Negara (Fungsi Budgetair) dan sebagai pengatur pelaksanaan kegiatan pemerintah di bidang sosial ekonomi dan di luar bidang keuangan (fungsi regularend). Pemerintah memiliki peran penting mengenai fungsi pajak sebagai regularend (pengatur) karena kebijakan peraturan yang ditetapkan pemerintah akan digunakan sebagai dasar hukum antara pemerintah dengan wajib pajak serta perlindungan fiskus dan wajib pajak. Sistem pemungutan pajak mengalami reformasi dari official menjadi self assessment. Wajib pajak melaporkan, menghitung sendiri jumlah pajak yang seharusnya terhutang dan Pemerintah memberikan kepercayaan penuh kepada Wajib Pajak. Sistem baru ini menuntut keaktifan serta kejujuran wajib pajak untuk melaksanakan kewajiban perpajakannya sedangkan fungsi pengawasan penegakan hukum pemeriksaan dan penyidikan pajak) dilakukan oleh pemungut pajak.

Self self assessment ini menimbulkan banyaknya wajib pajak yang akan melakukan penghindaran pajak dan akan berdampak pada penerimaan pajak (Friskianti dan Bestari, 2014). Wajib pajak yang tidak melaksanakan kewajiban perpajakannya akan mempengaruhi penerimaan pajak dan menimbulkan tunggakan pajak. Direktur Jendral Pajak akan melakukan pemeriksaan dan penagihan pajak kepada wajib pajak apabila ditemukan ketidaksesuaian pajak terhutang yang dilaporkan.

Penelitian mengenai faktor yang mempengaruhi penerimaan pajak telah dilakukan, diantaranya Puspitha dan Ni Luh (2018), Renata dkk (2016),Sitio (2015) dan Trisnayanti dan I 
Ketut (2015) akan tetapi hasilnya masih berbeda- beda. Penelitian ini perlu dilakukan karena pendapatan negara terbesar yaitu dari PPN dan tujuan dari penelitian ini adalah menguji sistem self assessment, pemeriksaan dan penagihan pajak serta inflasi terhadap penerimaan pajak PPN.

\section{KAJIAN TEORI DAN PENGEMBANGAN HIPOTESA Kajian Teori \\ Teori Akuntansi Perpajakan}

Teori akuntansi perpajakan ialah sebuah aktivitas untuk mencatat laporan keuangan, untuk menentukan besaran pajak terutang yang wajib dibayarkan (Purwono, Herry 2010).

\section{Teori Kontribusi}

Teori kontribusi yaitu pengetahuan tentang perpajakan yang melibatkan Wajib Pajak untuk berusaha lebih patuh dalam memenuhi pembayaran pajak terutang, guna meningkatkan penerimaan pajak yang ada (Astuti dan Inggrid, 2017).

\section{Self Assessment System}

Self Assessment System yakni sistem untuk memberi kepercayaan dan tanggungjawab terhadap Wajib Pajak dalam melakukan hak perpajakannya secara mandiri (Friskianti dan Bestari, 2014). Pengukuran self assessment system (Trisnayanti dan I Ketut, 2015):

\section{Jumlah SPT Masa PPN bulan ini-Jumlah SPT Masa PPN bulan lalu}

$$
\text { Jumlah SPT Masa PPN bulan lalu }
$$

\section{Pemeriksaan Pajak}

Pemeriksaan pajak ialah kegiatan pengumpulan data, keterangan maupun alat bukti yang dijalankan dengan teliti dan objektif sesuai standar pemeriksaan perpajakan dalam ketentuan perundang-undangan yang berlaku (Mardiasmo, 2016:56). Berikut perhitungan pemeriksaan pajak ialah (Trisnayanti dan I Ketut, 2015):

$$
\frac{\text { Jumlah nilai SKP tiap bulan }}{\text { Jumlah total nilai PPN yang diterima tiap bulan }} \times 100 \%
$$

\section{Penagihan Pajak}

Penagihan pajak ialah serangkaian tindakan yang digunakan untuk menegur, memperingatkan dan memberitahukan Surat Paksa serta melakukan pencegahan terhadap Wajib Pajak agar memenuhi tunggakan pajak dan biaya penagihan pajak (Mardiasmo, 2016:151). Perhitungan penagihan pajak yaitu (Trisnayanti dan I Ketut, 2015):

\section{$\frac{\text { Jumlah tunggakan pajak yang berhasil tertagih tiap bulan }}{\text { Jumlah total tunggakan pajak tiap bulan }} \times 100 \%$}

\section{Inflasi}

Inflasi ialah keadaan naiknya harga secara terus menerus yang mengakibatkan menurunnya nilai mata uang (Renata dkk, 2016). Berikut adalah rumus yang digunakan untuk mengitung inflasi (Fahmi, 2018:64-65):

$$
\text { Inflasi }=\frac{I H K_{x}-I H K_{x-1}}{I H K_{x-1}} \times 100 \%
$$

\section{Penerimaan Pajak Pertambahan Nilai (PPN)}

Penerimaan Pajak Pertambahan Nilai adalah pajak atas barang konsumsi dan jasa yang digunakan dalam menghentikan jalur produksi dan distribusi secara beringkat dalam wilayah 
pabean untuk meningkatkan penerimaan negara ( Sitio, 2015). Perhitungan penerimaan PPN yaitu (Trisnayanti dan I Ketut, 2015):

Jumlah PPN bulan ini-Jumlah PPN bulan lalu

Jumlah PPN bulan law

\section{Pengembangan Hipotesa}

Sistem pemungutan pajak di Indonesia saat ini adalah self assessment system. Dengan menggunakan sistem ini diharapkan peningkatan kesadaran dan kewajiban perpajakan Wajib Pajak. Mengingat bahwa kesadaran Wajib Pajak yaitu faktor terpenting dalam peningkatan penerimaan pajak (Bradley, 1994). Surat Pemberitahuan Masa PPN merupakan salah satu bentuk dari self assessment system itu sendiri. Surat Pemberitahuan masa merupakan bentuk pelaporan Pengusahan Kena Pajak (PKP) dan sebagai bentuk tanggungjawab atas pajak terhutang.

H1 : Self Assessment System berpengaruh terhadap penerimaan PPN

Penghimpunan dan pengolahan data, keterangan yang dilakukan secata objektif dan profesional merupakan rangkaian bentuk dari pemeriksaan. Pemeriksaan yang dilakukan ini berdasarkan pada standar pemeriksaan dan ketentuan perpajakan yang berlaku (Mardiasmo, 2016:56-57). Pencegah kecurangan yang akan dilakukan oleh Wajib Pajak dapat diminimalisir melalui pemeriksaan pajak. Jika pajak yang dibayarkan dengan yang dilaporkan Wajib Pajak dilakukan secara jujur, maka jumlah pajak yang terhutang telah sesuai dengan ketentuan yang berlaku dan penerimaan pajak yang diterima akan meningkat dan.

$\mathrm{H} 2$ : Pemeriksaan Pajak berpengaruh terhadap penerimaan PPN

Pelunasan utang pajak dan biaya pajak melalui peneguran, pemberian peringatan, pemberian Surat Paksa dan penyitaan barang kepada penanggung pajak disebut penagihan pajak (Mardiasmo, 2016:151). Penagihan pajak yang dilakukan oleh Direktorat Jenderal Pajak (DJP) secara optimal akan meningkatkan penerimaan pajak.

H3 : Penagihan Pajak berpengaruh terhadap penerimaan PPN

Inflasi adalah proses kenaikan harga barang umum secara terus menerus dan nilai tukar uang melemah (Renata dkk, 2016). Semakin tinggi nilai inflasi maka pengenaan DPP atas konsumsi barang dan jasa akan semakin meningkan dan akan berdampak pada penerimaan PPN (Puspitha dan Ni Luh, 2018).

H4 : Inflasi berpengaruh terhadap penerimaan PPN

\section{METODE PENELITIAN}

Penerimaan pajak pertambahan nilai (PPN) Wajib Pajak Badan pada kantor pelayanan pajak (KPP) Pratama di Surabaya Karangpilang merupakan pepulasi penelitian. Pengambilan sampel dengan Purposive sampling dan pengumpulan data diperoleh dari dokumentasi laporan SPT Masa PPN, jumlah nilai SKP PPN, jumlah penerimaan pajak pertambahan nilai (PPN), jumlah nilai STP yang ditagih dan diterima pada Kantor Pelayanan Pajak (KPP) Pratama di Surabaya Karangpilang serta data penelitian ini diperoleh dari laporan tingkat inflasi di Bank Indonesia (BI). 


\section{HASIL DAN PEMBAHASAN}

Berikut adalah hasil pengujian yang telah dilakukan oleh peneliti :

1. Asumsi Klasik

\begin{tabular}{llr} 
Msi Klasik & & \multicolumn{1}{c}{$\begin{array}{r}\text { Unstandardized } \\
\text { Residual }\end{array}$} \\
\hline Normal Parametersa,b & Mean & 48 \\
\cline { 2 - 3 } & Std. Deviation & .0000000 \\
\hline \multirow{2}{*}{ Most Extreme Differences } & Absolute & .048082782 \\
\cline { 2 - 3 } & Positive & .074 \\
\cline { 2 - 3 } & Negative & -.060 \\
\hline Test Statistic & & .074 \\
\hline Asymp. Sig. (2-tailed) & & $.200^{c, d}$ \\
\hline
\end{tabular}

\section{Gambar 3. Hasil Uji Normalitas}

Berdasarkan hasil uji normalitas dapat disimpulkan bahwa masing-masing variabel memiliki nilai residual berdistribusi normal karnea nilai Asymp. Sig. (2-tailed) > tingkat signifikansi $(\square)$ sebesar 0,050 .

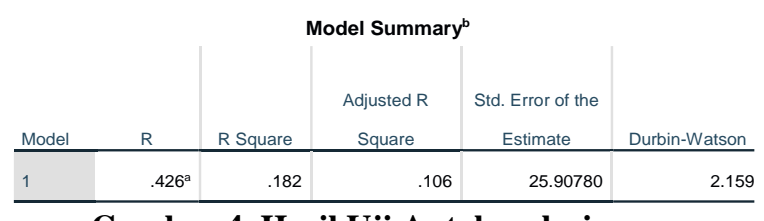

Gambar 4. Hasil Uji Autokorelasi

Gambar 4 menunjukkan nilai 4 - dU= 4 - 1,7206 yaitu 2,2794 $(1,7206<2,159<2,2794)$, maka hasil pengujian dengan menggunakan D-W test menghasilkan tidak terjadi gejala autokorelasi.

Berdasarkan hasil output pada gambar 5 menunjukkan pengambilan keputusan antara variabel independent dengan unstandardized residual yaitu nilai signifikansi > tingkat kesalahan yaitu $0.05(5 \%)$ yang artinya persamaan regresi tidak berkorelasi atau mengandung heteroskedastisitas.

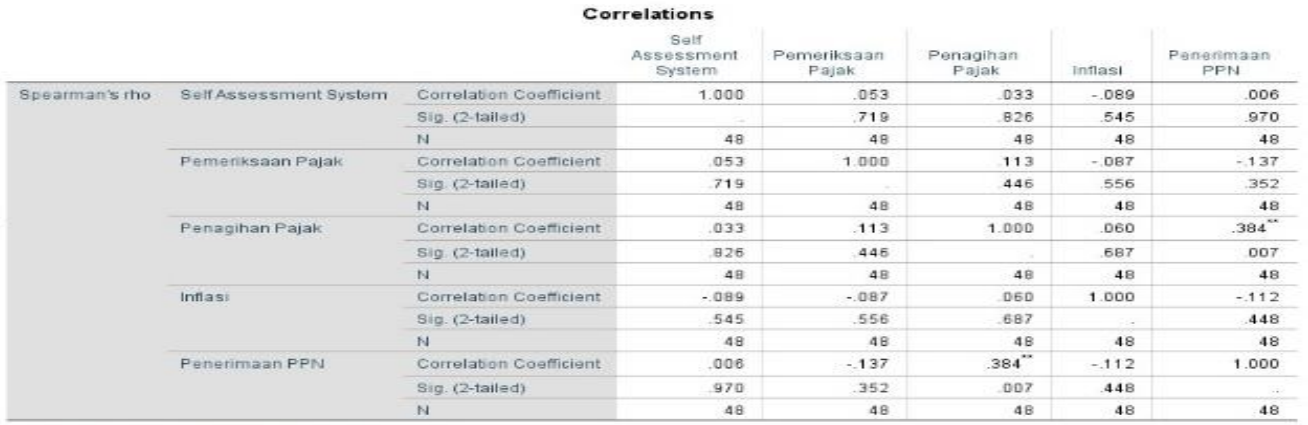

Gambar 5. Hasil Uji heteroskedastisitas

2. Uji Multikolinieritas

Coefficientsa

\begin{tabular}{|c|c|c|c|}
\hline \multicolumn{4}{|c|}{ Coefficients ${ }^{a}$} \\
\hline \multirow{2}{*}{\multicolumn{2}{|c|}{ Model }} & \multicolumn{2}{|c|}{ Collinearity Statistics } \\
\hline & & Tolerance & VIF \\
\hline \multirow[t]{5}{*}{1} & (Constant) & & \\
\hline & $\begin{array}{l}\text { Self Assessment } \\
\text { System }\end{array}$ & .962 & 1.040 \\
\hline & Pemeriksaan Pajak & .998 & 1.002 \\
\hline & Penagihan Pajak & .971 & 1.030 \\
\hline & Inflasi & .987 & 1.013 \\
\hline
\end{tabular}

Gambar 6. Hasil Uji Multikolinearitas 
Berdasarkan dari hasil output SPSS, maka dapat diketahui bahwa tidak ada gejala multikolinearitas karena setiap variabel nilai tolerance $>0.10$ dan VIF $<10.00$.

3. Analisis Regresi Berganda

Berdasarkan gambar 7 dapat disimpulkan bahwa variabel self assessment sistem, pemeriksaan pajak dan inflasi tidak berpengaruh terhadap variabel penerimaan PPN sedangkan penagihan pajak berpengaruh terhadap variabel penerimaan PPN pada KPP Pratama Surabaya Karangpilang.

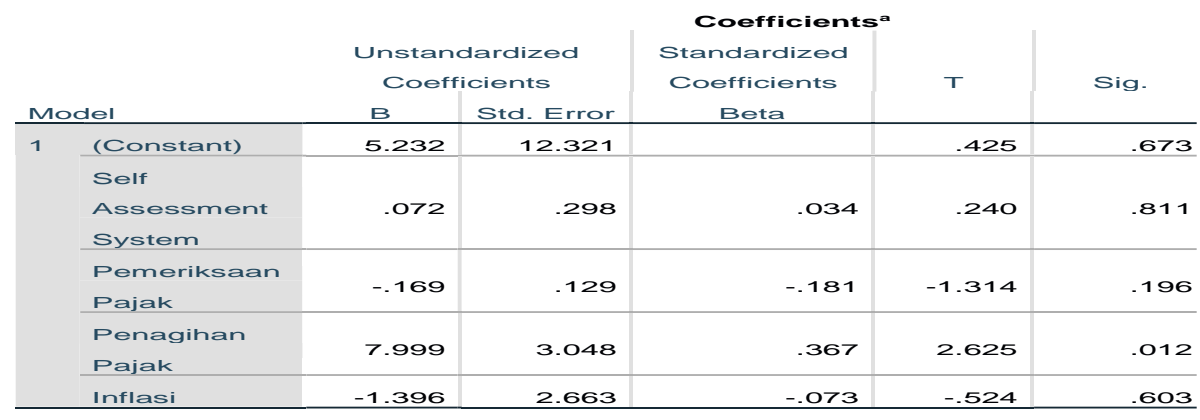

Gambar 7. Hasil Uji Regresi

Self assessment sistem membebaskan dan memberikan kepercayaan langsung kepada WP atas hak perpajakannya sehingga WP diharapkan aktif dan patuh untuk melaksanakan kewajibannya. Akan tetapi realisasinya potensi pajak yang ada belum dapat digali dan terdapat kemungkinan adanya potensi ketidaksesuaian dan penyimpangan dalam prakteknya baik akibat kelalaian ataupun ketidaktahuan WP dalam melaksanakan kewajiban perpajakan yang dapat menimbulkan tunggakan pajak dan mengakibatkan berkurangnya penerimaan pajak negara, dengan demikian WP harus memiliki kesadaran dan kepatuhan yang tinggi dalam melaksanakan hak perpajakannya. Penelitian ini sejalan dengan penelitian Maulida dan Addnan (2017) dan tidak mendukung penelitian Ivon Trisnayanti, Ida dan I Jati (2015).

Pemeriksaan pajak yaitu kegiatan mengolah dan menghimpun data maupun bukti secara objektif berdasarkan standar pemeriksaan yang berlaku. Pemeriksaan dan pendeteksian kecurangan yang dilakukan oleh WP dapat melalui pemeriksaan pajak. Hasil pemeriksaan pajak berupa surat ketetapan pajak dan surat tagihan pajak. Apabila WP tidak melunasi kewajibannya dari pemeriksaan yang telah dilakukan akan mengakibatkan penunggakan pajak.

Pemeriksaan pajak tidak berpengaruh terhadap penerimaan pajak PPN karena nilai dari penerbitan Surat Ketetapan Pajak Kurang Bayar (SKPKB) tidak diikuti dengan pelaporan dan kewajiban perpajakan. Penerbitan SKPKB tidak dapat mendorong WP untuk melakukan pelunasan pajak. Hasil penelitian ini sejalan dengan penelitian Prihastanti dan Kiswanto (2015). Akan tetapi tidak mendukung dalam penelitian Ivon Trisnayanti dan I Jati (2015).

Penagihan Pajak berperngaruh terhadap penerimaan pajak PPN. Dengan adanya punishment yang diberikan oleh Dirjen pajak dapat mendorong WP membayar pajak, melunasi utang pajak dan biaya penagihan pajak. Punishment ini berupa teguran dan peringatan sampai dengan penyitaan asset wajib pajak. Hasil hipotesis ini mendukung penelitian Ivon Trisnayanti, Ida dan I Jati (2015)

Penurunan daya beli dan konsumsi masyarakat dapat menurunkan pendapatan tetap karena nilai riil mata uang akan menurun jika inflasi terjadi. Inflasi mengakibatkan kuantitas 
barang yang dibeli akan berkurang karena harga barang naik secara terus-menerus sedangkan penerimaan pajak akan tetap sama dan tidak terjadi adanya kenaikan penerimaan pajak. Fluktuasi ekonomi tinggi dapat menimbulkan turunnya daya beli konsumen, investasi, ekspor impor yang kemudian akan berdampak pada penerimaan PPN. Hasil penelitian ini sejalan dengan penelitian Puspitha dan Ni Luh (2018) dan tidak mendukung dalam penelitian Renata, dkk (2016).

\section{KESIMPULAN DAN SARAN}

Hasil pengujian menunjukkan hanya penagihan pajak berpengaruh terhadap penerimaan pajak sedangkan Self Assessment System, penagihan pajak dan inflasi tidak berpengaruh terhadap Penerimaan PPN. Hasil penelitian ini masih bersifat sementara dan dapat dikaji ulang oleh peneliti selanjutnya, dalam hal ini peneliti menyadari akan keterbatasan, antara lain Bagi peneliti selanjutnya yaitu disarankan untuk menggunakan atau menambah variabel independent lain yang dapat mempengaruhi penerimaan PPN. Hasil penelitian ini manunjukkan kesadaran masyarakat mengenai pajak masih kurang hal ini ditunjukkan dengan masih banyaknya kewajiban masyarakat yang belum terpenuhi, sehingga KPP dapat melakukan peningkatan kegiatan melalui penyuluhan, penagihan pajak sehingga dapat memaksimalkan penerimaan pajak

\section{DAFTAR PUSTAKA}

Astuti, Aliya Nur Putri dan Inggrid Panjaitan. (2017) . "Pengaruh E-Fakntur dan Pengetahuan Pajak Terhadap Penerimaan Pajak Dengan Kepatuhan Wajib Pajak Sebagai Variabel Moderating Pada Kantor Pelayanan Pajak Pratama Sunter, Jakarta Utara." Media Akuntansi Perpajakan. Vol. 2, No. 1: 1-13. ISSN (P):2355-9993 (E):2527953X.

Bradley, Cassie Francies. (1994). An Empirical Investigation of Factor Affecting Corporate Tax Compliance Behavior. Dissertation. The University Alamaba, USA.

Friskianti, Yossi, dan Bestari Dwi Handayani. (2014). "Pengaruh Self Assessment System, Keadilan, Teknologi Perpajakan, Dan Ketidakpercayaan Kepada Pihak Fiskus Terhadap Tindakan Tax Evasion." Accounting Analysis Journal 3(4): 543-52.

Ivon Trisnayanti, Ida, dan I Jati. (2015). "Pengaruh Self Assessment System, Pemeriksaan Pajak, Dan Penagihan Pajak Pada Penerimaan Pajak Pertambahan Nilai (Ppn)." EJurnal Akuntansi 13(1): 292-310.

Mardiasmo. (2016). Perpajakan Edisi Terbaru 2016. Yogyakarta: ANDI.

Maulida, Cut Inayatul dan Adnan. (2017). Pengaruh Self Assessment System, Pemeriksaan Pajak dan Penaguhan Pajak Terhadap Penerimaan Pajak Pertambahan Nilai (PPN) Pada KPP Pratama Banda Aceh. Jurnal Imliah Mahasiswa Ekonomi Akuntansi (JIMEKA). Vol. 2 No. 4

Pasaribu, Benny. 2011. Analisis Fakntor Yang Mempengaruhi Indeks Harga Saham Sektor Industri Barang Konsumsi Di Pasar Modal Indonesia. Jakarta: PT. Indeks

Purwono, Herry. (2010). Dasar-dasar Perpajakan dan Akuntansi Pajak. Jakarta: Erlangga.

Puspitha, Putu Vilia dan Ni Luh Supadmi. 2018. Pengaruh Pertumbuhan Ekonomi dan Inflasi Pada Penerimaan PPN (Studi Kasus pada Kantor Pelayanan Pajak se-Bali). E-Jurnal Akuntansi. Vol. 22.2: 1530-1556, ISSN: 2302-8556, Universitas Udayana.

Prihastanti, Rosy dan Kiswanto. (2015). Tingkat Kepatuhan Wajib Pajak Badan Terhadap Penrimaan Pajak Dimoderasi Oleh Pemeriksaan Pajak. Accounting Analysis Journal. Vol 4 No 1

Resmi, Siti. (2019). Perpajakan Teori dan Kasus. Jakarta : Salemba Empat 
Renata, Almira Herna, Kadarisman Hidayat, dan Bayu Kaniskha. (2016). Pengaruh Inflasi, Nilai Tukar Rupiah dan Jumlah Pengusaha Kena Pajak Terhadap Penerimaan Pajak Pertambahan Nilai. 9(1): 1-9.

Sitio, Rohmasari. (2015). "Pengaruh Self Assessment System, Penerbitan Surat Tagihan Pajak Dan Penagihan Pajak Dengan Surat Paksa Terhadap Penerimaan Pajak Pertambahan Nilai Pada Kpp Madya Dan Kpp Pratama Tampan Pekanbaru." Jurnal Online Mahasiswa Fakultas Ekonomi Universitas Riau 2(2): 1-15.

Trisnayanti, Ida Ayu Ivon dan I Ketut Jati. (2015). Pengaruh Self Assessment System, Pemeriksaan Pajak dan Penagihan Pajak Pada Penerimaan Pajak Pertambahan Nilai (PPN). Jurnal Akuntansi Uniersitas Udayana. Vol 13. No. 1

Wijayanti, Amalia. 2015. "Analisis Penerimaan Pajak Indonesia: Pendekatan Ekonomi Makro. Semarang: Fakultas Ekonomika dan Bisnis.

www.kemenkeu.go.id diakses pada 23 Juni 2020 Pukul 10.59

www.pajak.go.id diakes pada 22 Juni Pukul 08.00 